\title{
The Effectiveness of Token Economy to Reduce Truant Behavior
}

\author{
Samurya Rahmadhony \\ Faculty of Psychology, Airlangga University of Surabaya, Indonesia \\ samurya.erde@gmail.com
}

\begin{abstract}
Keyword:

Token economy;

Truant;

Elementary school.

Truant is a behavior caused by a lack of control of behavior. Token economy is a form of positive renforcement where the subject receives a token when they exhibit the desired behavior. Data analysis was carried out in three stages, namely visual analysis, different tests using the Wilcoxon Signed Rank Test and calculating the effest size. Token economy interventions effectively reduce truant behavior in 5th grade elementary school students who have lived in class.
\end{abstract}

Article History:

Received: 03-02-2019

Revised : 28-03-2019

Accepted: 29-04-2019

Online : 30-04-2019

\author{
This is an open access article under theCC-BY-SA license \\ Crossref \\ https://doi.org/10.31764/ijeca.v2i1.2038
}

\section{A. INTRODUCTION}

Education is one of the inseparable aspects in human life. Education takes place in all types, forms and levels of the environment which then encourages the growth of all the potential that exists in individuals (Bunga Widita Kartikasari, Mifbakhuddin, 2011). The potential that exists in these individuals can be used as much as possible to create good quality education.

For the sake of achieving good quality education, through Law No. 20 yr. 2003, Republic of Indonesia regulates the national education system. Chapter II article 3 explains that the function of national education is to develop capabilities, shape the character and civilization of a dignified nation. In addition, it was explained, in the context of educating the life of the nation, students were required to be human beings who had faith and were devoted to God Almighty, noble, healthy, knowledgeable, capable, creative, independent, and became citizens who were democratic and responsible.

The above statement means that the quality of an education has received oversight from all parties including the government. While in reality, the main problem that is often discussed by teachers and guardians of students in the framework of character education is the issue of discipline in the school. One form of violation of discipline in the school environment is truant (Smirnova, 2019).

Mogulescu\& Segal (Mogulescu \& Segal, 2002), explained that 75\% - 85\% of forms of disciplinary violations in adolescents are truant or are very often absent from school. Prihartanto (Prihartanto, 2013) found truant behavior to be at the first rating as a form of disciplinary violation. Research on truancy conducted by Garrison (Garrison et al., 2004) revealed that the reasons for students being absent from school were $30 \%$ due to missed buses, 
$2.8 \%$ mostly slept, $3.7 \%$ were sick and $63.5 \%$ due to other factors that were not controlled in the study. Furthermore explained truant behavior in students showed $70.4 \%$ of students with male sex had played truant and $29.6 \%$ of students with female sex. This shows that truancy in boys is higher than girls.

Truant is leaving school without a good reason at class time and not prior permission to the school (Gunarsa, 2019). Furthermore Kartono (Kartono, 2017) explains that truant is a behavior that violates social norms and is a result of a poor environmental conditioning process. Kristiyani (Kristiyani, 2015) truant behavior is also known as truancy. This behavior is done in a way, students still leave the house in the morning in uniform, but they are not at school. It can be concluded that truant is the behavior of students who do not go to school for reasons that are not right, or can also be said to be absent without a clear reason.

Truant habits that are often done by students will have a negative impact on him and his environment. Students who get caught skipping class will be punished, suspended, unable to take the exam, or even expelled from school. Truant habits is a behavior caused by a lack of control of behavior, so we need a way to help students' problems in controlling their behavior.

Damayanti (Damayanti, 2018) explains truant habits are certainly influenced by internal factors and external factors. Next explained internal factors that make students play truant that is lazy to go to school, less attention from parents. While external factors that make students excuse to play truant are subjects that are less desirable.

Based on the explanation above, it is necessary to intervene the students to be able to control their behavior in truant behavior. There are several interventions that can be done to control his behavior in truant behavior, one of which is to provide token economy interventions. Token economy is one of the techniques in behavior modification. Token economy is a form of positive renforcement where the subject receives a token when they exhibit the desired behavior. After subjects accumulate a certain amount of tokens, they can exchange them for reinforcers (Erford, 2019).

Ried (Bardhoshi et al., 2016) explains that there are several stages that must be passed when conducting an token economy, including determining the behavioral targets that need to be changed, creating rules and setting "prices". In token economy programs, behavioral targets can vary depending on individual characteristics and the state of their environment. The main criteria for choosing behavioral targets are behaviors that are beneficial to the individual and those around him. After the target behavior is identified, the behavior must be clearly defined so that it is easier to administer the token. Reid proposes to specifically mention those behaviors and describe standards for performance that are considered satisfactory.

The subject must also understand the rules in granting tokens, the quantity of tokens given for expected behavior, and when clients can exchange tokens to get reinforcers. The type of token given should be, safe, strong, easy to give, and the suit to be replicated. Furthermore, reinforcers can be discussed with clients when they exchange tokens so that reinforcers have a certain significance or appeal to clients.

After the subject understands the rules in granting tokens, the next step is to choose how many tokens the subject must have before exchanging them with reinforcers. Reid explained that before implementing the system, the first stage of testing the price of the reinforcer is accurate enough and the subject can collect enough tokens to exchange the reinforcer. So that the subject does not lose motivation to engage in the desired behavior. 


\section{B. METHODS}

The research used was a quasi-experimental design using single subject design. This design uses research subjects with a small number of subjects by examining how changes in individual behavior after given a certain treatment (Blackmore, 2009). This research was conducted on 12year-old subjects complained of by the homeroom teacher and the BK teacher because they often missed school (truant), often slept in class, did not do homework and rarely did school work. The subject was also complained by the principal because he often behaved in violation of school rules and had no information for 30 days off. In addition, the subject also did not go up in grade 5 elementary school and predicted did not move up the class in the same class. The subject's behavior is also complained of by parents and the subject's parents have difficulty in regulating the subject's behavior.

Measurement of dependent variables on research with a single subject design is carried out repeatedly with a certain period of time. Comparisons are not made between individuals and groups, but on the same subject under different conditions (Sunanto, 2019). The conditions in question are baseline or conditions before treatment is given, and experimental conditions or after treatment is given. Comparison between the baseline phase with at least one intervention phase is always done. Single subject design can be in the form of several subjects in a group or the subject under study is single ( $\mathrm{N}=1$ ) (Sundberg et al., 2002). Further explained, research with $(\mathrm{N}=1)$ is widely used in behavioral oriented research. Clinical research, education, psychiatry and medicine can use a single subject design (Lukman et al., 2019).

Research with a single subject design generally consists of two categories, namely 1) A reversal design consisting of three types, A-B design, A-B-A design, and A-B-A-B design. 2) multiple baseline design consisting of multiple cross conditions, multiple baseline cross variables, and multiple baseline cross subjects (Sunanto, 2019). In this study, the single subject research design used is the A-B design, where $\mathrm{A}$ is the baseline and $\mathrm{B}$ is the intervention phase. The design of this study did not replicate the baseline and intervention phases so that both the baseline (A) and intervention (B) phases were only performed once on the same subject. The main procedure carried out in this study is to take measurements at the baseline phase to obtain a trend or stable data level, so that later intervention can be carried out. The change in results in the intervention phase after compared with the baseline can be assumed as a form of change due to the influence of the independent variables or interventions that have been carried out.

The intervention module given in this study is a program design based on B.F theory. Skinner. This intervention module goes through a review process conducted by professional judgment. The experts provide criticisms and suggestions that researchers use as a basis for improving the modules that have been prepared. The results show that in general the module is good and can be used.

This intervention module is divided into 5 sessions plus the pre-session that will be given for 6 days. This intervention is carried out in individual settings in accordance with the modules that have been prepared. The following is a general description of each intervention session:

Table 1. Token Economy Module

\begin{tabular}{cccl}
\hline Session & Duration & Activity & \multicolumn{1}{c}{ Purpose } \\
\hline Pre-session & 30 & Build rapport & $\begin{array}{l}\text { Introducing, explaining the purpose and } \\
\text { stages of the activity and filling out } \\
\text { informed consent. }\end{array}$ \\
\hline
\end{tabular}




\begin{tabular}{|c|c|c|c|}
\hline \multirow[t]{3}{*}{$\begin{array}{l}\text { Session I } \\
\text { (Identification } \\
\text { of } \\
\text { problematic } \\
\text { behavior) }\end{array}$} & \multirow[t]{3}{*}{$\begin{array}{c}60 \\
\text { minutes }\end{array}$} & $\begin{array}{l}\text { The researcher asks the } \\
\text { subject to remember the } \\
\text { problematic behavior that } \\
\text { was done and the originator } \\
\text { of the emergence of the } \\
\text { behavior. }\end{array}$ & \multirow[t]{3}{*}{$\begin{array}{l}\text { Subjects can evaluate the problematic } \\
\text { behavior that has been done and are } \\
\text { willing to change the behavior. }\end{array}$} \\
\hline & & $\begin{array}{l}\text { Researchers explain the } \\
\text { impact of these behaviors. }\end{array}$ & \\
\hline & & $\begin{array}{l}\text { The subject is willing to } \\
\text { change the behavior. }\end{array}$ & \\
\hline \multirow[t]{3}{*}{$\begin{array}{l}\text { Session II } \\
\text { (Making } \\
\text { rules) }\end{array}$} & $\begin{array}{c}60 \\
\text { minutes }\end{array}$ & $\begin{array}{l}\text { Researchers explain what } \\
\text { behavior is carried out so as } \\
\text { to get a token. }\end{array}$ & \multirow{3}{*}{$\begin{array}{l}\text { The subject understands the rules in } \\
\text { granting tokens, when the tokens will } \\
\text { be given, discussing the types of prizes } \\
\text { (reinforcers), and signing of token } \\
\text { economy intervention contracts. }\end{array}$} \\
\hline & & $\begin{array}{l}\text { Subjects were asked to name } \\
\text { the prize they most liked }\end{array}$ & \\
\hline & & $\begin{array}{l}\text { Subjects were asked to read } \\
\text { and sign an intervention } \\
\text { contract. }\end{array}$ & \\
\hline \multirow{2}{*}{$\begin{array}{l}\text { Session III } \\
\text { (Setting } \\
\text { reinforcer } \\
\text { prices) }\end{array}$} & $\begin{array}{c}45 \\
\text { minutes }\end{array}$ & $\begin{array}{l}\text { The researcher explains how } \\
\text { many tokens are obtained for } \\
\text { each reinforcer }\end{array}$ & \multirow{2}{*}{$\begin{array}{l}\text { Subjects understand the many stickers } \\
\text { that must be collected in exchanging } \\
\text { gifts and when subjects can exchange } \\
\text { gifts. }\end{array}$} \\
\hline & & $\begin{array}{l}\text { Researchers mention the } \\
\text { schedule and place to } \\
\text { exchange tokens. }\end{array}$ & \\
\hline \multirow[t]{2}{*}{$\begin{array}{l}\text { Session IV } \\
\text { (Reinforcer } \\
\text { exchange) }\end{array}$} & $\begin{array}{c}45 \\
\text { minutes }\end{array}$ & $\begin{array}{l}\text { Researchers and subjects } \\
\text { count the number of tokens } \\
\text { collected }\end{array}$ & \multirow[t]{2}{*}{$\begin{array}{l}\text { The subject exchanges the stickers that } \\
\text { have been collected with the agreed } \\
\text { prize. }\end{array}$} \\
\hline & & $\begin{array}{l}\text { Researchers provide } \\
\text { reinforcers }\end{array}$ & \\
\hline \multirow{2}{*}{$\begin{array}{l}\text { Session V } \\
\text { (Evaluation } \\
\text { and } \\
\text { termination) }\end{array}$} & $\begin{array}{c}60 \\
\text { minutes }\end{array}$ & $\begin{array}{l}\text { Researchers evaluate the } \\
\text { changes that occur in the } \\
\text { subject's behavior }\end{array}$ & \multirow[t]{2}{*}{ Terminate the intervention process } \\
\hline & & $\begin{array}{l}\text { The researcher is grateful and } \\
\text { ends the intervention process }\end{array}$ & \\
\hline
\end{tabular}

Arikunto (Suharsimi;, 2013) explains the method of data collection is a tool for evaluating and measuring the data obtained. The research instrument used to measure truant behavior was absent documentation, observation and interviews with the homeroom teacher. Documentation comes from the word document, which means a record of events in the form of writing, pictures, or monumental works of someone (Sugiyono, 2017). Documentation includes data collection activities in the form of archives or documents that support this research data. The use of documentation methods aims to obtain visual data as authentic evidence about the object to be examined.

In this study other data collection methods come from observations and interviews. Observation described a method of collecting data in a specific way and is composed of a process of observation and memory. Observations in this study were carried out throughout the research process, especially during the intervention process both before, during and after the intervention was given. Observation aims to determine the subject's attitudes and behavior in showing his involvement, sincerity, and commitment during the intervention process. While the interviews were conducted with subject teachers. The interviews used are semi-structured. 
There is a list of questions to be asked on the research subjects so that the interview process does not deviate from the stated goals (Jackson, 2012).

Data analysis will be carried out in three stages, namely visual analysis, different tests using the Wilcoxon Signed Rank Test and calculating the effect size. Visual analysis is a visual analysis of data that refers to an accurate graphical representation of various measurement data. Data is taken at all observation phases with specific reference to the difference between preintervention (baseline) and the intervention phase or session (Wash, 2019). Pallant (Pallant, 2007) states that the Wilcoxon signed rank test is designed to be used in repeated measurements. In this study the Wilcoxon Signed Rank Test is used to test differences in truant behavior in subjects before and after the intervention. The difference in scores in this test will reflect the level of success of the interventions that have been carried out. An effect size is a set of statistics that shows the relative magnitude of the difference between the mean, or the total number of variants in the dependent variable that can be predicted from the knowledge of the level of the independent variable (Pallant, 2007).

\section{RESULT AND DISCUSSION}

The purpose of this study was to examine the effectiveness of token economy interventions to reduce truant behavior in 5th grade students who have lived in classes. The method used in this study is a single subject design with the number of subjects 1 person. The analysis used in the single subject design method is visual analysis on the score results graph in each session. Sunanto and colleagues (Sunanto, 2019) state that this type of method is sensitive to analyzing differences in individual changes in each condition. This is because the comparison of results is not carried out between individuals and groups but is compared on the same subject under different conditions.

The results of visual analysis on the subject show a trend towards the graph or a downward trend. The subject also showed a change in truant behavior from 4 times a week in the basline phase to change into never ditching the end of the intervention phase. This shows that the subjects in this study experienced a decline in truant behavior. This result is also reinforced by the calculation of overlap data on subjects that show overlapping data ranges of $0 \%-25 \%$. Based on the overlap data range, it can be concluded that the token economy intervention in this study has a major influence on the decline in truant behavior of the subject, which is $75 \%-$ $100 \%$.

Another analysis conducted on the results of this study is a different test analysis with Wilcoxon signed-rank test. Based on the results of statistical tests with Wilcoxon signed-rank test obtained a significance level of 0,068 . This value is greater than 0,05 which means that there is no significant difference in the behavior of truant subjects before and after token economy intervention is given. In each session in the intervention phase the subject actually experienced a decline in truant behavior, this is evidenced by the mean pretest and posttest descriptive test results. The mean value of all posttest data is smaller than the pretest value. This was also strengthened by the results of the effect size testing which resulted in a score of 0.913 in the large effect category. Both of these prove that there is a change in conditions or a decline in truant behavior in the subject after undergoing token economy intervention.

Different test results that show no significant difference between the subject's condition before and after the intervention can be due to the measurement time which is only about one week after the intervention is given. Chiesa and Serreti stated that the insignificant difference in truant behavior after and before the intervention was due to the intervening evaluation interval 
being too close. The timeframe that has proven effective in seeing significant differences is 2 to 3 months after the intervention has been given. In addition, the existence of insignificant values on Wilcoxon test results itself can be caused by the number of study samples that are too small (Azwar, 2011).

The success of an intervention is determined by the awareness of the research subject (Sisworo \& Dkk, 2016). In this study token economy intervention can reduce truant behavior for several reasons. In the first session, subjects were asked to be aware of the problematic behavior carried out and analyze the impact of the behavior. This process makes the subject more aware of how the problematic behavior affects the views of family, parents, school and himself. The subject is able to recognize the problematic behavior that has been done and understand the impact of the behavior so that the subject is willing to change the behavior.

In the second session intervention subjects were asked to name and rate the desired reinforcer. The type of reinforcer in token economy intervention to reduce truant behavior must be adjusted to the wishes of the subject. In this research the types of reinforcers used are gadget playing vouchers, internet cafe playing vouchers, football watching tickets and futsal shoes.

Token economy intervention is a behavioristic approach that can control behavioral problems such as truant behavior. This technique requires collaboration with related parties such as homeroom teacher, school counselor, school principal and parents in supervising the intervention. Consistency in intervening in token economy is held firmly by the homeroom teacher, school counselor, principal, parents and researchers as learning for children to be disciplined. Every expected behavior appears, given a token. Vice versa every unexpected behavior appears for any reason, the subject is not given a token. This is in line with Severe that consistently does as said and handles behavior in the right way.

\section{CONCLUSION AND ADVICE}

Based on the results of data analysis and discussion of research that has been done, it can be concluded that token economy intervention is effective in reducing truant behavior in 5th grade elementary school students who have lived in classes. The results of the effectiveness test showed a value of 0,913 , which means that token economy interventions had a large effect on decreasing truant behavior in 5th grade elementary school students who had lived in classes.Research development on token economy can be combined with other intervention techniques such as extinction. Researchers can then conduct other studies with large groups or samples that are adapted to the conditions in the field.

\section{REFERENCES}

Azwar, S. (2011). Reliabilitas Dan Validitas. Yogyakarta: Pustaka Pelajar, 19.

Bardhoshi, G., Erford, B. T., Duncan, K., Dummett, B., Falco, M., Deferio, K., \& Kraft, J. (2016). Choosing Assessment Instruments for Posttraumatic Stress Disorder Screening and Outcome Research. Journal of Counseling and Development, 94(2), 184-194. https://doi.org/10.1002/jcad.12075

Blackmore, N. (2009). Barry Horner. Money Marketing, 45. http://search.ebscohost.com/login.aspx?direct=true\&db=bth\&AN=44972280\&lang=tr\&site=ehostlive

Bunga Widita Kartikasari, Mifbakhuddin, D. N. M. (2011). Hubungan Pendidikan, paritas, dan Pekerjaan Ibu Dengan Status Gizi Ibu Hamil Trimester III di Puskesmas Bangetayu Kecamatan Genuk Kota Semarang Tahun 2011. Jurnal Unimus, 3, 2.

Damayanti, D. (2018). Sistem Informasi Akuntansi Penerimaan Dan Pengeluaran Kas Pada Kpri Andan Jejama Kabupaten Pesawaran. Jurnal Tekno Kompak, 57. 
https://doi.org/10.33365/jtk.v12i2.152

Erford, B. T. (2019). Accountability in Group Work. In Group Work (pp. 155-180). https://doi.org/10.4324/9781351110679-8

Garrison, D. R., Anderson, T., \& Archer, W. (2004). Cognitive Presence_Final.pdf. Garrison, 1-24.

Gunarsa, S. M. (2019). Kontrak Berjangka Komoditas Emas Sebagai Instrumen Transaksi Derivatif dalam Kajian Hukum Ekonomi Syariah. Undang: Jurnal Hukum, 2(1), 95-117. https://doi.org/10.22437/ujh.2.1.95-117

Jackson. (2012). JAX Mice Pup Appearance by Age. Jackson, 114(10), 6423. https://doi.org/1-800-4226423

Kartono, K. (2017). FAKTOR - Faktor Yang Mempengaruhi Kinerja Manajerial (Studi Kasus Pada Perusahaan Daerah Air Minum di Wilayah III Cirebon. JURISMA : Jurnal Riset Bisnis \& Manajemen, 6(1). https://doi.org/10.34010/jurisma.v6i1.451

Kristiyani, I. (2015). Penerapan Etika Kantor dalam Pencitraan Organisasi. Efisiensi - Kajian Ilmu Administrasi, 11(1). https://doi.org/10.21831/efisiensi.v11i1.3981

Lukman, I. A., Latipun, L., \& Hasanati, N. (2019). Pengaruh Stres Kerja Terhadap Performa Kerja Dimoderasi Oleh Manajemen Diri Pada Guru Honorer SD Di Banda Aceh. Jurnal Diversita, 5(2), 126. https://doi.org/10.31289/diversita.v5i2.3030

Mogulescu, S., \& Segal, H. J. (2002). Approaches to truancy prevention. Youth Justice, October.

Pallant, J. (2007). A Step-by-Step Guide to Data Analysis Using SPSS for Windows (Version 15), 3rd Edition. In Allen and Unwin.

Prihartanto, C. (2013). Analisis Faktor-faktor yang Mempengaruhi Kepatuhan Wajib Pajak Dalam Melakukan Pemberdayaan Pajak Bumi dan Bangunan Perdesaan dan Perkotaan. Journal of Chemical Information and Modeling, 53(9), 1689-1699. https://doi.org/10.1017/CB09781107415324.004

Sisworo, \& Dkk. (2016). Analisis Kemampuan Berpikir Kritis. Prosiding Konferensi Nasional Penelitian Matematika Dan Pembelajarannya, 3(Knpmp I), 580-590. https://doi.org/10.23971/eds.v5i2.732

Smirnova, V. N. (2019). Scientific and technical translation training in the conditions of electronic information and educational environment in the construction university. Open Education, 23(2), 413. https://doi.org/10.21686/1818-4243-2019-2-4-13

Sugiyono. (2017). Sugiyono, Metode Penelitian. Penelitian, 34-45. https://doi.org/10.1021/ol7029646

Suharsimi; , A. (2013). Dasar-Dasar Evaluasi Pendidikan. In Jakarta: Bumi Aksara (p. 168).

Sunanto, S. (2019). Pengaruh faktor individu dan lingkungan terhadap keputusan mahasiswa menjadi wirausaha studi kasus pada mahasiswa universitas pamulang. Jurnal ilmiah feasible (JIF), 1(1), 1. https://doi.org/10.32493/fb.v1i1.2019.1-8.2261

Sundberg, N. D., Winebarger, A. A., \& Taplin, J. R. (2002). Clinical psychology: Evolving theory, practice, and research. Clinical Psychology: Evolving Theory, Practice, and Research.

Wash, J. (2019). Responsible Investment Issues in Special Economic Zone Investment in Mainland Southeast Asia. VNU Journal of Science: Economics and Business, 35(2). https://doi.org/10.25073/2588-1108/vnueab.4226 